\title{
NATUREZA, ORGANISMOS E MÁQUINAS PARA O AMANHÃ ENCONTROS INESPERADOS ENTRE ARTE, CIÊNCIA E FILOSOFIA
}

\author{
NATURE, ORGANISMS AND MACHINES FOR TOMORROW UNEXPECTED \\ ENCOUNTERS BETWEEN ART, SCIENCE AND PHILOSOPHY
}

\begin{abstract}
Antonio Almeida da Silva ${ }^{1}$
Resumo: Engendra aqui encontros (in)esperados entre Arte, Ciência e Filosofia para pensar as máquinas e os organismos para as condições do antropoceno. Experimentemos com movimentos trazidos pelas pinturas de Fernando Vicente e as experimentações de Angelo Vermeulen que produzem e ressignificam (com) outras naturezas tecno e geneticamente inventadas, pondo outras questões à contemporaneidade. Nesse diálogo contemporâneo encontramos algumas reflexões nos estudos de Simondon, Deleuze e Guattari, Haraway, entre outros que apostam em novas interfaces da natureza. Nas diferentes produções artísticas a tecnologia e a máquina não são apenas apresentadas como uma simples ferramenta. Metais, placas de silício, elementos inorgânicos e de transição, entre outras diferentes manifestações da tecnologia, são acoplados aos seres vivos e vice e versa, a serviço de uma poética. Assim, seres orgânicos e inorgânicos evoluem conjuntamente para novas interfaces do ser. É nesse cenário que nossa pesquisa inventa outras narrativas para pensar a relação entre ciência, arte e filosofia. Palavras-chave: Arte-Máquina; natureza; filosofia.
\end{abstract}

\begin{abstract}
Here we engage in (un) expected encounters between Art, Science and Philosophy to think of machines and organisms for the conditions of the anthropocene. Let us experiment with the movements brought by the paintings of Fernando Vicente and the experiments of Angelo Vermeulen that produce and resignify (with) other techno and genetically invented natures, posing other issues to the contemporaneity. In this contemporary dialogue we find some reflections in the studies of Simondon, Deleuze, and Guattari, Haraway, among others, who bet on new interfaces of nature. In different artistic productions, technology and the machine are not just presented as a simple tool. Metals, silicon plates, inorganic and transition elements, among other different manifestations of technology, are coupled to living beings and vice versa in the service of poetics. Thus, organic and inorganic beings evolve together towards new interfaces of being. It is in this scenario that our research invents other narratives to think about the relationship between science, art and philosophy.
\end{abstract}

Keywords: Art-Machines; nature; philosophy.

\section{Introdução}

O presente artigo se lança e se arrisca diante de algumas experiências de escrever com as produções contemporâneas que trazem outras abordagens sobre a máquina e a natureza, tal escrita faz parte de alguns estudos iniciados no meu Doutorado em Educação pela Faculdade de Educação da Unicamp, com a tese "Laboratórios dos despropósitos: vestígios ecológicos entre arte e ciência" defendida em 2018. Seguimos com o artigo:

Engendra uma possível natureza para as condições do amanhã, seres humano-animais, humano-vegetais estabelecem novas condições para o antropoceno. Artificialidades sistêmicas que diluem as fronteiras existentes entre ciência, ficção e arte. Uma natureza para o amanhã que pensa

\footnotetext{
${ }^{1}$ Professor doutor da Universidade Estadual de Feira de Santana - UEFS, E-mail: almeida.uefs@ @mail.com.
} 
outros modos de existência entre humanos, animais e máquinas a partir dos encontros interfronteiriços entre arte, ciência e filosofia. Num fluxo muito acelerado, a ciência vem inventando novos dispositivos maquínicos, instaurando uma nova era placentária, e a arte contemporânea acompanha e se insere nesse cenário de forma crítica não deixando de ser inovadora e criativa.

Essas novas tecnologias, direta ou diretamente, apresentam um projeto de reconfiguração da natureza e ao mesmo tempo, de acordo com Tomaz Tadeu (2009), também da dissolução do humano.

"Estamos dentro daquilo que fazemos e aquilo que fazemos está dentro de nós. Vivemos em um mundo de conexões - e é importante saber quem é que é feito e desfeito". (TADEU, 2009, p. 32).

Talvez o desafio maior seja criar novas formas de relação com o outro, seja qualquer outro, humano, animais, plantas, minerais e até mesmo as máquinas. Propor um pacto, uma convenção em prol de um mundo mais sustentável. Diante de uma ameaça invisível, fruto do próprio descontrole econômico e capitalista, torna-se necessário, juntar-se forças. O presente artigo também pode ser pensado em uma espécie de um manifesto onde buscam-se encontros inesperados entre aquilo que possamos chamar de natureza e seus organismos, as máquinas para pensar em um mundo mais sustentável.

Assim, buscamos perceber através da arte contemporânea algumas produções que capturam e ao mesmo tempo são capturadas pelas forças da natureza e sua relação direta com as máquinas, mas especificamente aquela que traz consigo certa apreensão poética e ao mesmo tempo subversiva entre a interface organismo-máquina. Assim, somos o tempo todo provocados pela seguinte questão: quais produções artísticas trazem abordagens inusitadas para pensar na relação interespecífica entre organismo-máquina? O que essas produções artísticas, que exploram temas como artificialismo e natureza podem contribuir para os encontros inesperados entre Arte, Ciência e Filosofia?

Diante dessas perguntas, que não terão respostas simples e tão pouco prontas, o presente artigo aposta nas indissociabilidades entre natureza-humano, humano-máquina e suas variáveis, tudo está em um complexo de fluxos que se engendram e modulam individuando-se em novos compostos, seres e coisas, onde a arte contemporânea pode trazer outras abordagens dessas relações que serão investigadas.

Uma das características mais notáveis desta nossa era (...) é o promíscuo acoplamento, a desavergonhada conjunção entre o humano e a máquina. Em um nível mais abstrato, em um nível 'mais alto', essa promiscuidade generalizada traduz-se em uma inextrincável confusão entre ciência e política, entre tecnologia e sociedade, entre natureza e cultura. Não existe nada mais que seja simplesmente 'puro' (TADEU, 2009, p. 11).

O que talvez precisamos é inventar outras configurações de existências, outros moldes para esse sujeito que vem sendo engendrado, pois, como diz Haraway (2009), o sujeito vaza por todos os lados. Nesse artigo pretendeu-se investigar quais artistas da contemporaneidade poderiam trazer outras imagens naturezas, organismos e máquinas para pensarmos em novas relações com o contemporâneo. Apostamos (nos espaços de interconexão entre arte, filosofia e ciência) nos processos de simbiose, protocooperação, metamorfoses, acoplamentos, individuações entre máquinas e humanos entre organismos e compostos inorgânicos, contudo, não podemos esquecer de mencionar que as máquinas também engendram um cenário tenebroso, produzindo deformações, mutações, num processo de anulamento da vida.

Nossos caminhos e escolhas metodológicas buscam na arte contemporânea, através das práticas artísticas, outras perspectivas e conexões improváveis ou inesperadas. E para pensar nas novas interfaces entre os corpos orgânicos e inorgânicos que estão por vir, selecionamos dois importantes artistas contemporâneos: Fernando Vicente, através das obras "Vanitas", 
"Vênus" e "Anatomías", e as experimentações bioartísticas: "Biomondd" e "Corrupted C \# n \# m \#" de Angelo Vermeulen.

Pensamos com Deleuze e Guattari (1992) entre outros pensadores aqui apresentados, como aproximar a arte contemporânea da ciência e da filosofia. Compreenderemos, assim, que esses diferentes campos não se diferenciam a partir de uma matriz comum, o que nos permite aproximar um saber do outro são as intensas e interessantes relações de conexão. "Também há tanta criação em ciência quanto na filosofia ou nas artes. Nenhuma criação existe sem experiência" (DELEUZE; GUATTARI, 1992, p. 166).

Entre esse diálogo contemporâneo entre máquina e natureza encontramos algumas reflexões filosóficas nos estudos de Gilbert Simondon (2015), Gilles Deleuze (1974), Deleuze e Guattari (1992, 1997), Donna Haraway (2009), Tomaz Tadeu (2009), entre outros apostam novas interfaces da natureza. No bojo de novas manifestações da natureza, emergem da arte contemporânea formas não convencionais de apresentar a natureza, dando a natureza novas interfaces. Inter-Expor a natureza em conectividade, interfaces virtuais e reais. Entre mestiçagens e hibridismos instaura-se uma conjunção poética da estratificação e da conjunção entre o primitivo e o inédito, engendram novos fluxos de genes no ritmo de vida dos diferentes seres.

Como a ciência, a filosofia e arte nos ajudam a pensar as novas relações entre natureza e máquina apontando para contemporâneo novos desafios, diálogos e reflexões? Como ser afetado por esses encontros? Experimentamos na arte um modo de escrever filosofia, pensar na arte e ciências como potências abertas ao devir criativo. Essas e outras questões comporão formas de experimentar escritas, pesquisas e vida.

Pensamos aqui arriscar algumas possibilidades de experimentar derivações com os encontros entre os artistas e suas produções, tentando atravessar um pensamento com encontros com a filosofia, arrisquemos possibilidades escritas curatoriais para pensar diferentes processos de individuação que ocorrem no encontro do leitor/expectador com a obra do artista.

Também busquemos abordar reflexões bastantes contemporâneas sobre a interrelação entre as máquinas e a natureza, em Donna Haraway (2009), principalmente no conceito de cyborg e desafiamos a relacionar as noções de individuações de Gilbert Simondon (2015) com diferentes produções contemporâneas.

Arte, ciência e filosofia estabelecem diálogos e arranjos, que criam metamorfoses e deslocam as imagens para compor com as naturezas inusitadas.

Entendemos que esses encontros possam trazer novas possibilidades de abordagens e de criação, propor formas de pensar e escrever sobre a natureza, tanto no que se refere ao natural, como no que diz respeito à cultura, assim, como compreender e experimentar a vida de forma distinta, onde podemos escapar de uma dualidade de forças entre o inorgânico e o orgânico para apostar nas redes, intersecções, interconectores e simbioses entre esses.

Explorar, assim como faz Deleuze e Guattari (1997), os lugares de indeterminação e de indiscernabilidade entre os diferentes elementos, onde animal, vegetal e mineral se tornam indiscerníveis.

É sob a égide dos processos de individuação que se dá a mais íntima relação entre o orgânico e o inorgânico; já não se trata de função ou invasão, mas origens comuns, gêneses comuns. Processos múltiplos acontecem, desde a (des)constituição, (des)codificação, (des)solução e (des)feixes de informações. (SILVA, 2018, p. 40).

A relação que estabelecemos com a arte contemporânea, ciência e filosofia nos permite imaginar outros modos de pensar e conceber a natureza e criar novas reflexões com o mundo contemporâneo, tais reflexões que nos permitem conhecer mais adiante, a fazer conexões inesperadas com situações improváveis que o cotidiano apresenta. 
Nesse sentido, os artistas inventam relações entre organismos e máquinas, que vão além do utilitarismo, instrumentalismo e submissão, mas de uma dupla existência. Essas práticas só se dão pela relação constante de experimentações de simbioses e conjunções entre o orgânico e o inorgânico para pensar as novas interfaces naturais e artificiais, de inventar outros arranjos, experimentar e inventar outras práticas na/para contemporaneidade através dos trabalhos de alguns artistas da contemporaneidade. Alguns artistas experimentam diálogos com a natureza e seus artificialismos, tais como: Fernando Vicente e Angelo Vermeulen, entre outros. Nas diferentes produções artísticas, a tecnologia, a máquina, não é apenas apresentada como uma simples ferramenta, metais, placas de silício, elementos inorgânicos e de transição, entre outras diferentes manifestações da tecnologia, que são acopladas aos seres vivos a serviço de uma poética e uma coexistência. Assim, seres orgânicos e inorgânicos evoluem conjuntamente para novas interfaces do ser.

Fernando Vicente nos apresenta, nas séries "Vanitas", "Vênus" e "Anatomías", imagens de corpos quase humanos e quase mecânicos, uma dupla captura de forças que experimentam com as forças e fraquezas humanas: a vaidade, a beleza e a vitalidade se contaminam pelas ferrugens do tempo. Modelos-máquinas mostram suas feridas deixando vazar, tal como um pus, os excessos da forma.

Nas séries "Vanitas" e "Vênus", as pinturas anatômicas dialogam com a dualidade entre a fusão da beleza física e a realidade científica, a vaidade exterior dos corpos deixa escapar os diagramas complexos da sua própria anatomia interior, entre fraturas e invasões da pele, o artista apresenta uma combinação bastante peculiar entre arte e ciência.

Em "Vênus", o artista, por meio do pincel, abre o tecido cutâneo tal como um bisturi e, assim, arranca e revela as interfaces das musas da pintura clássica, descamando suas intimidades anatômicas mais internas.

Uma clássica captura de um gesto, um gesto de vaidade e de beleza, mas que não pode esconder a vulnerabilidade do corpo e da futilidade dos mundanos prazeres. Um corpo que pousa diante da câmera para uma revista de moda. Um corpo que ao fingir ser elegante acaba revelando a fragilidade e a efemeridade da vida. Entre vísceras, artérias, nervos e músculos, revela-se uma self de um corpo a flor da pele, sem subterfúgios. Um enquadramento faustoso que não consegue escapar da certeza da morte e da finitude da vida. A série Vanitas"e "Vênus" denunciam o insuporável diante da aparente beleza que se apresenta na exterioridade, tal condicionamento mecânico e quase automático para atender aos padrões da moda.

Para Haraway (2009), a condição cyborg está no organismo cibernético, um híbrido máquina e organismo, um criatura de realidade social e também uma criatura de ficção, é uma construção política, social, é uma matéria de opressão, alienação e uma construção social.

"Trata-se de uma luta de vida e morte, mas a fronteira entre a ficção científica e a realidade social, onde o mostruoso, o pertubador, a realidade, a natureza antes escondida por esses padrões sociotécnicos da beleza agora vazam e já não passam despercebidos". (HARAWAY, 2009, p. 36)

Numa forte relação entre o sensível e o inteligível, acompanhados da beleza e de um sentimento sublime desses corpos esteticametne pradonizados.

Paul Klee apud Lyotard (1997) "A arte não imita a natureza, cria um mundo ao lado", paralelamente a essa afirmação, disse: "o monstruoso e o disforme têm os seus direitos, já que podem ser sublimes". (LYOTARD, 1997, p. 102)

Nas pinturas em "Vanitas" e "Vênus", o artista abre meticulosamente o corpo de suas jovens modelos comparando diversos planos anatômicos numa mesma imagem. Seus altas

\footnotetext{
${ }^{2}$ Vanitas, conceito trazido pela arte seiscentista, que se estende até hoje nos nossos dias. Um estilo de arte que faz emprego de naturezas-mortas, além de o emprego de algumas expressões emocionais como: alegria, tristeza, raiva. Algumas obras trazem expressões e símbolos religiosos emblemáticos, tais como pecado, urgia, vício, vaidade,
} 
anatômicos retratam rostos corriqueiros, retratando pessoas "reais", além disso, seus modelos são mulheres, diferentemente dos modelos anatômicos que geralmente são homens. Diferentemente dos atlas de medicina, que trazem corpos ausentes de personalidade, o artista, nas séries investigadas, desenha e pinta mulheres que podem estar no nosso cotidiano, mulheres lindas, magras, trazendo suas roupas, penteados, tatuagens, maquiagens, joias, etc. São mulheres poderosas que ostentam beleza, saúde e vaidade.

Entre vícios, vaidades, culto à forma, luxuria e os prazeres libidinais; mulheres belas e elegantes pousam para o retrato, onde a maquiagem tenta esconder da própria finitude que é a vida. O recorte dado à pintura aos órgãos, com a precisão de um bisturi, denunciam que a vida é efêmera, que tudo é provisório, fugidios são os prazeres da vida e que o corpo e seus órgãos, uma hora apodrece, assim, a pele, a maquiagem, a tatuagem, a etiqueta já não dão mais conta de esconder.

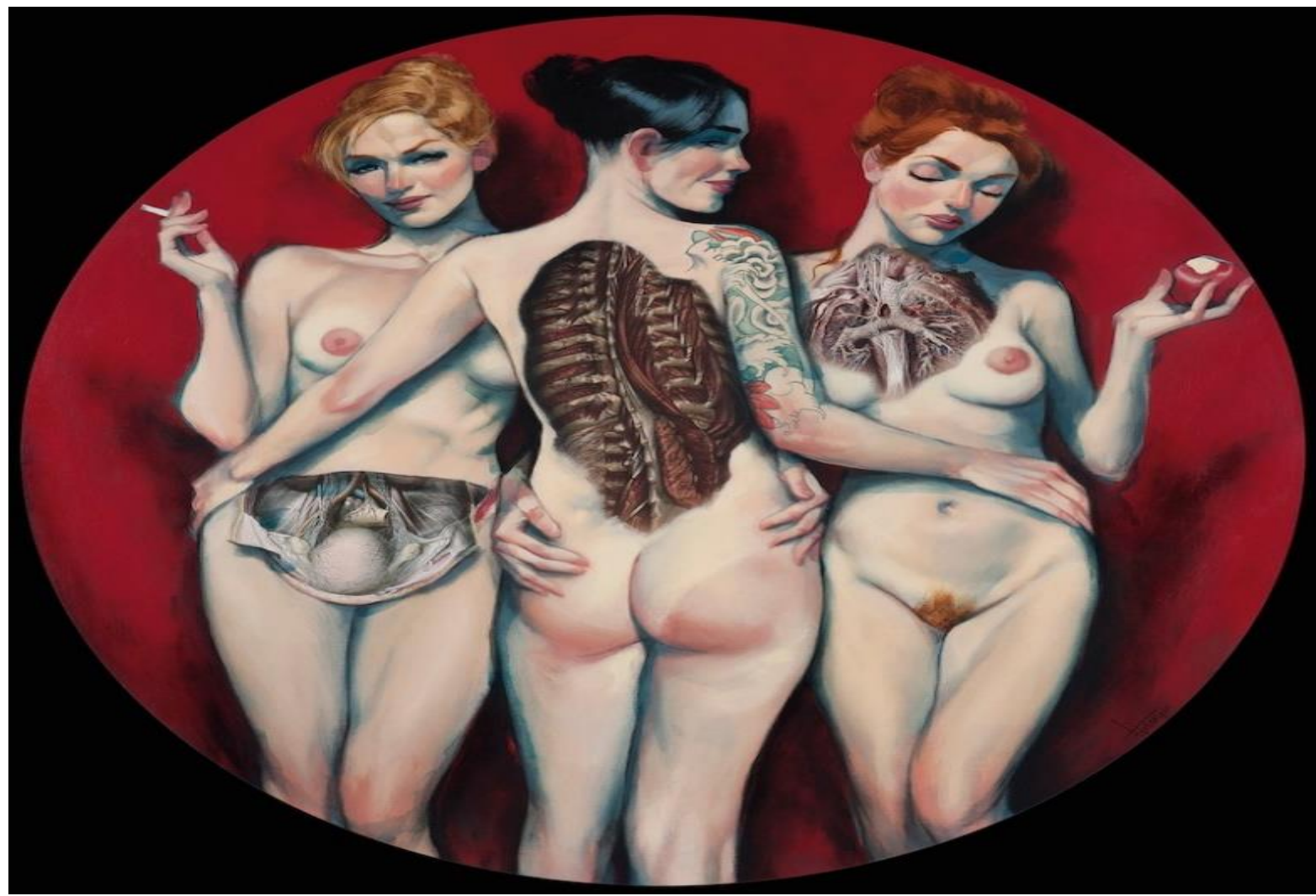

Figura 1: "Vanitas/Três Gracias", Fernando Vicente, 2016. - Fonte: site do artista.

A exposição de alguns órgãos na pintura traz a ideia da vulnerabilidade e a fragilidade da vida, mas, a sua presença, também, afirma que existe uma harmonia entre os tecidos, órgãos e todo corpo, isso pode se revelado através dos detalhes minuciosos na pintura que aos poucos revela ao expectador que todos somos iguais por dentro, que por dentro, apesar de nossas diferentes exterioridades, somos muito parecidos, a partir do momento que você rompe a epiderme, as exterioridades se anulam.

Essas dissecções-pinturas do contemporâneo expõem de forma científica e ao mesmo tempo artística as dicotomias entre a exterioridade e a interioridade, mas ao mesmo tempo nos faz pensar sobre esses padrões e modelos pós-humanos e maquínicos a que estamos condicionando nossas vidas. Mulheres vênus, vanitas, todas cyborgs, atendendo os padrões do mercado, prontas ao

que nos desvirtuam do caminho mais virtuoso e edificante. "Vanitas" (do latim, vacuidade, futilidade, algo vão, sem valor). 
consumo. Mulheres máquinas de produção, que se acoplam as necessidades do mercado. Mulheres com seus tecidos vivos que se conectam sistemicamente, maquinarias que se interligam organicamente. Mulheres todas cyborgs, que ao rasgar suas peles rompem seu lado humano.

Em "Anatomías" se projeta uma sombra de máquina na forma humana, seres ciberneticamente inventados para serem produtivos e desejantes, corpos sensuais com seu erotismo cravado na pele. Corpos que produzem automatismos mecânicos através dos gestos humanos, num paralelismo entre engrenagens, motores à flor da pele e corpos humanos.
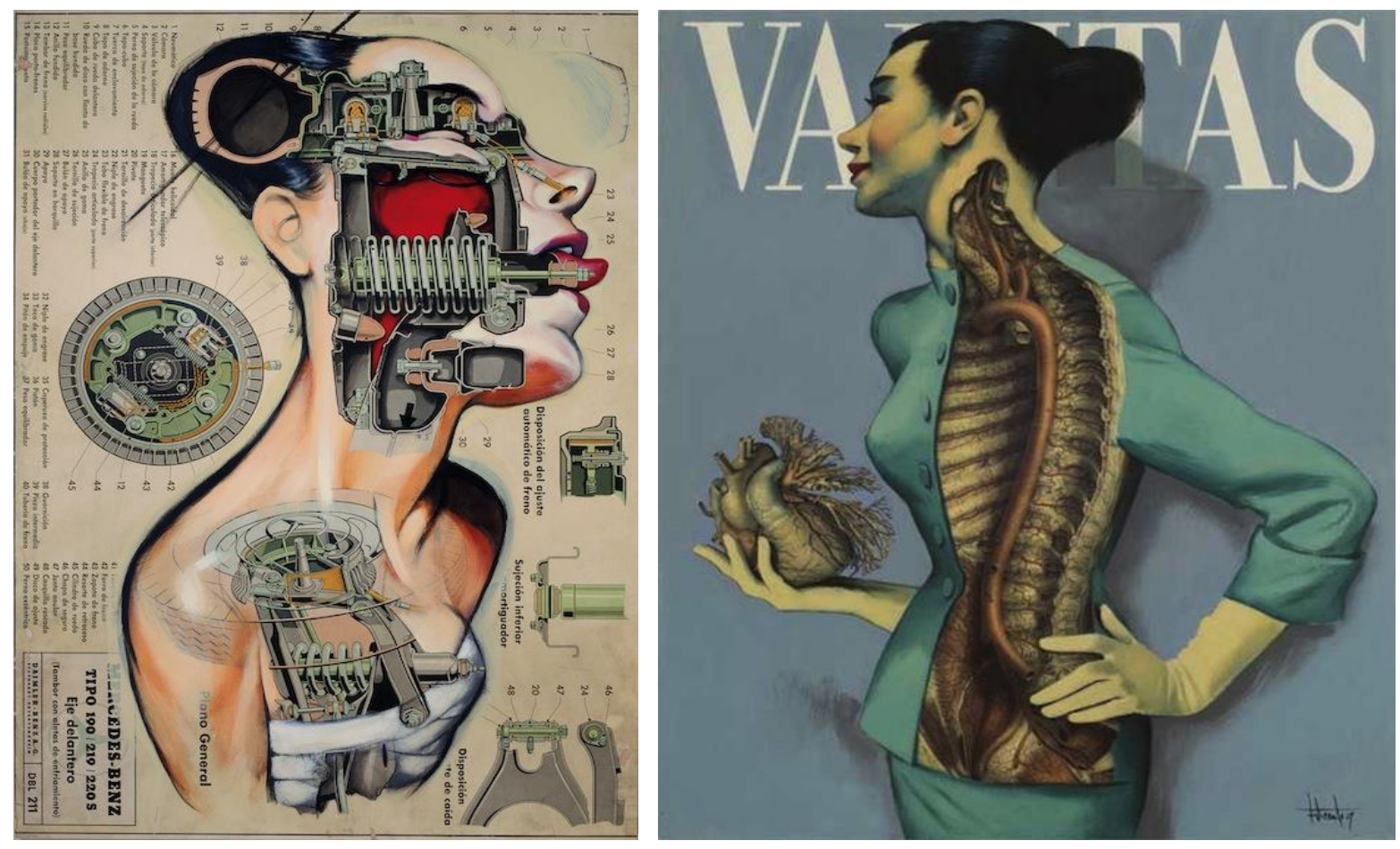

Figura 2: "Anatomías" /" Vanitas". (montagem autoria minha). Fernando Vicente, 2000. - Fonte: site do artista. ${ }^{3}$

Fernando Vicente dispõe figuras humano-máquinas em atlas, nomeando estruturas e parte do corpo em transição, tal como um guia, um manual para melhor conhecermos essa outra existência. Os atlas "Anatomías" de Fernando Vicente nos convidam a conhecer além do mero utilitarismo das máquinas, pois, toda relação depende do conhecimento do outro para podemos melhor fruir nossas próprias relações.

Voltemos aqui a pensar sobre as relações organo-máquinas trazidas pelos autores TOMAZ (2009) e HARAWAY (2009), que apostam na indissociabilidade entre a máquina e o humano.

A série "Anatomías" revela a mecânica das belas e sexy mulheres "CyberPunks", a beleza está na pele externa - orgânica e também no interior mecânico, com suas belas e complexas engrenagens, válvulas entre outras peças. Não estaríamos exagerando se por acaso disséssemos que o ser humano, gradativamente, incorpora características de uma máquina, ou que a máquina, por sua vez, aciona características humanas. Percebemos nas "Anatomías" uma nova simbiose entre o mecânico e o fisiológico.

Os corpos-máquinas abrem suas peles para revelar sua mecanicidade. Corpos que se rasgam como um corte de um bisturi, para dizer que todo o sistema é uma máquina só, que tudo trabalha em conjunto. Tanto nas "Vanitas", "Vênus" e "Anatomías", o modo cyborg se revela em diferentes camadas da epiderme, sendo externamente ou internamente.

\footnotetext{
${ }^{3}$ Fernando Vicente, 2000. Disponível em: http://www.fernandovicente.es/. Acesso em: 30 de abril 2020.
} 
Assim, apresentamos as obras de Fernando Vicente, para pensar a relação entre as máquinas e a natureza, na contemporaneidade, trazendo uma abordagem ao mesmo tempo crítica e harmônica de forma inusitada. Fernando Vicente entre uma pincelada e outra mistura o sublime ao disforme, numa composição criativa e muito distinta.

Outra forma inusitada para abordar a interface entre a natureza e as máquinas está nas produções do artista, biólogo e pesquisador de sistemas espaciais Angelo Vermeulen, que é fundador de um coletivo transdisciplinar internacional SEAD (Space Ecologies Art and Design). Vermeulen faz parte de um coletivo de artistas, cientistas, engenheiros e ativistas que tem como objetivo remodelar o futuro através de experimentações criativas, críticas e práticas. Para esse artigo traremos dois importantes trabalhos: Biomondd e Corrupted C \# n \# m \#.

Biomondd é um dos projetos artísticos mais conhecidos de Angelo Vermeulen, que consiste em uma série mundial de instalações interativas de arte nas quais os computadores coexistem como sistemas vivos internos. Biomondd desafia a ideia ecossistêmica da vida orgânica, colocando em conexão máquinas e organismos para desempenharem funções de interdependência, equilíbrio e correlação. Sistemas biomecânicos agenciando ecossistemas híbridos e dinâmicos. Biomodd é um sistema de protocooperação entre processadores dos computadores e algas.

Biomodd vem a ser uma instalação artística que tem no seu bojo as relações estabelecidas entre a biologia, as máquinas e os seres vivos. Resumindo, a ideia é criar relações simbióticas entre plantas e computadores e acender a discussão na comunidade científica e artística sobre esses processos de relação e cooperação entre máquinas e organismos

Por exemplo, as algas microscópicas são usadas simultaneamente para resfriar os processadores dos computadores quando esquentam, para que possam funcionar mais rapidamente, enquanto o calor gerado pelos componentes eletrônicos dos computadores é usado para criar condições ideais de crescimento para um ecossistema baseado em plantas. Ao esquentar os computadores dão um ambiente favorável para que as algas se desenvolvam, uma relação de troca constante, uma simbiose orgânico-máquina.
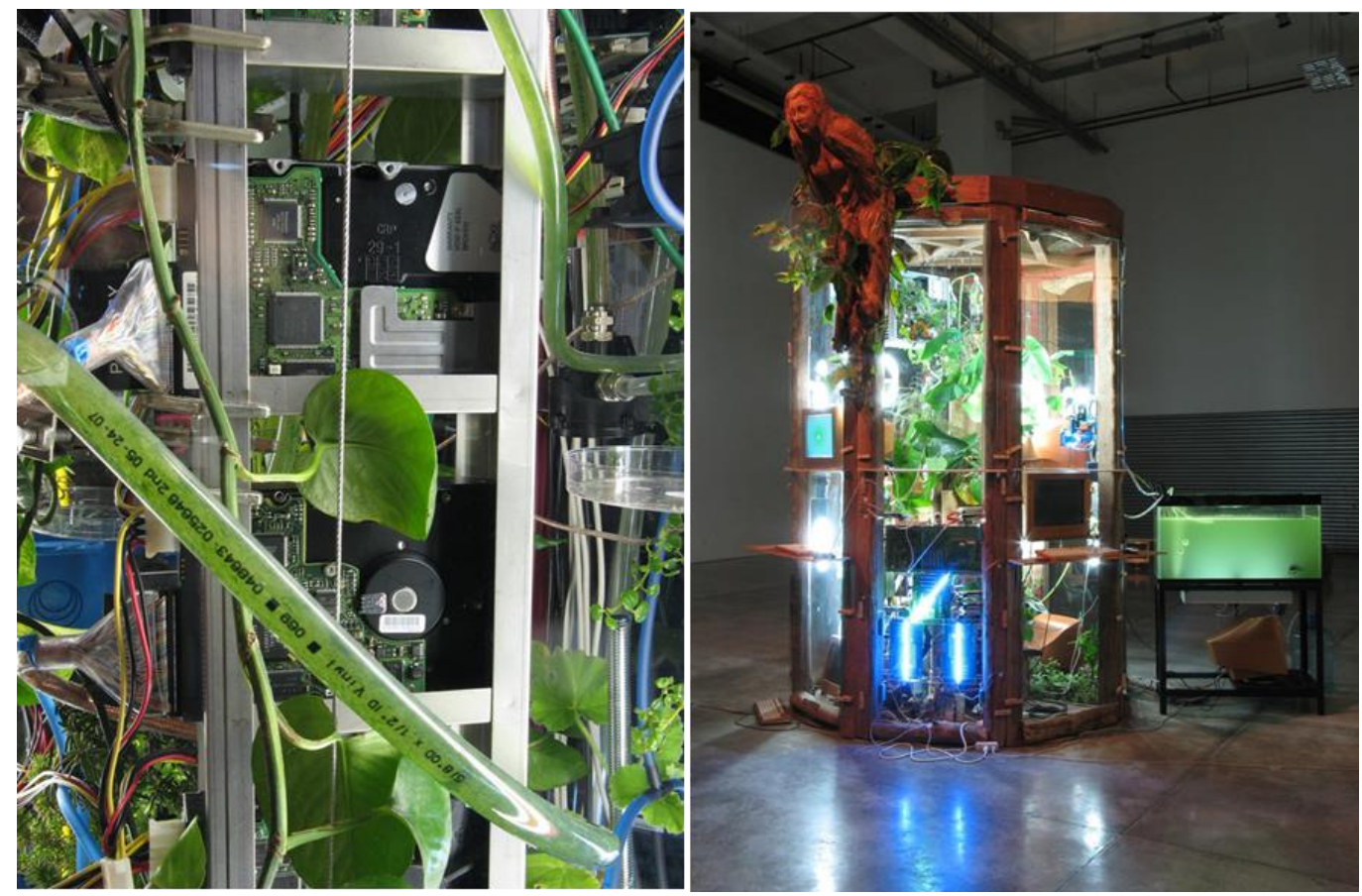

Figura 3: "Biomodd". (montagem autoria minha), Angelo Vermeulen, 2007. - Fonte: site do artista. 
Biomodd atua com um ecossistema auto-gerador, que aposta nessa dinâmica da catalisação entre os fluxos de diferentes organismos, essa também é a dinâmica do projeto e da equipe que incluem: artistas, biólogos, cientistas da computação, designers de jogos, jardineiros, e membros da comunidade local em que o projeto ocorre.

Outro projeto que traz essa relação entre organismos vivos e máquinas é a investigação artística Corrupted $\mathbf{C}$ \# $\mathbf{n}$ \# $\mathbf{m}$ \#, que tem por finalidade desafiar os paralelos e dialéticos entre a fisicalidade digital, infecção bacteriana e corrupção de dados e a experiência cinematográfica. "Corrupted C \# n \# m \#" traz essa importante questão: Como o crescimento da vida orgânica na mídia digital pode causar falhas digitais nos dados dos vídeos e nas mídias? Como definimos as (inter)relações entre o natural e o artificial? Que outras naturezas se engendram nessas relações?

Angelo Vermeulen e sua equipe experimenta corromper as imagens, os dados de arquivos digitais, disco, rígido, VHS, CDROM, fitas K-7, através da contaminação pelos microrganismos e insetos.

O artista cultiva os arquivos, tal como se cultiva em placas de Petri, os meios de culturas de microrganismos. Vermeulen reutiliza os arquivos de imagens e corrompem parcialmente seus dados através das interferências dos seres vivos criando nelas distorções, intervalos, quebras nas linearidades das imagens, dando as imagens novas modulações cinematográficas.

"El individuo es la relación activa, el intercambio entre lo intrínseco y lo extrínseco" (SIMONDON, 2015, p. 58).
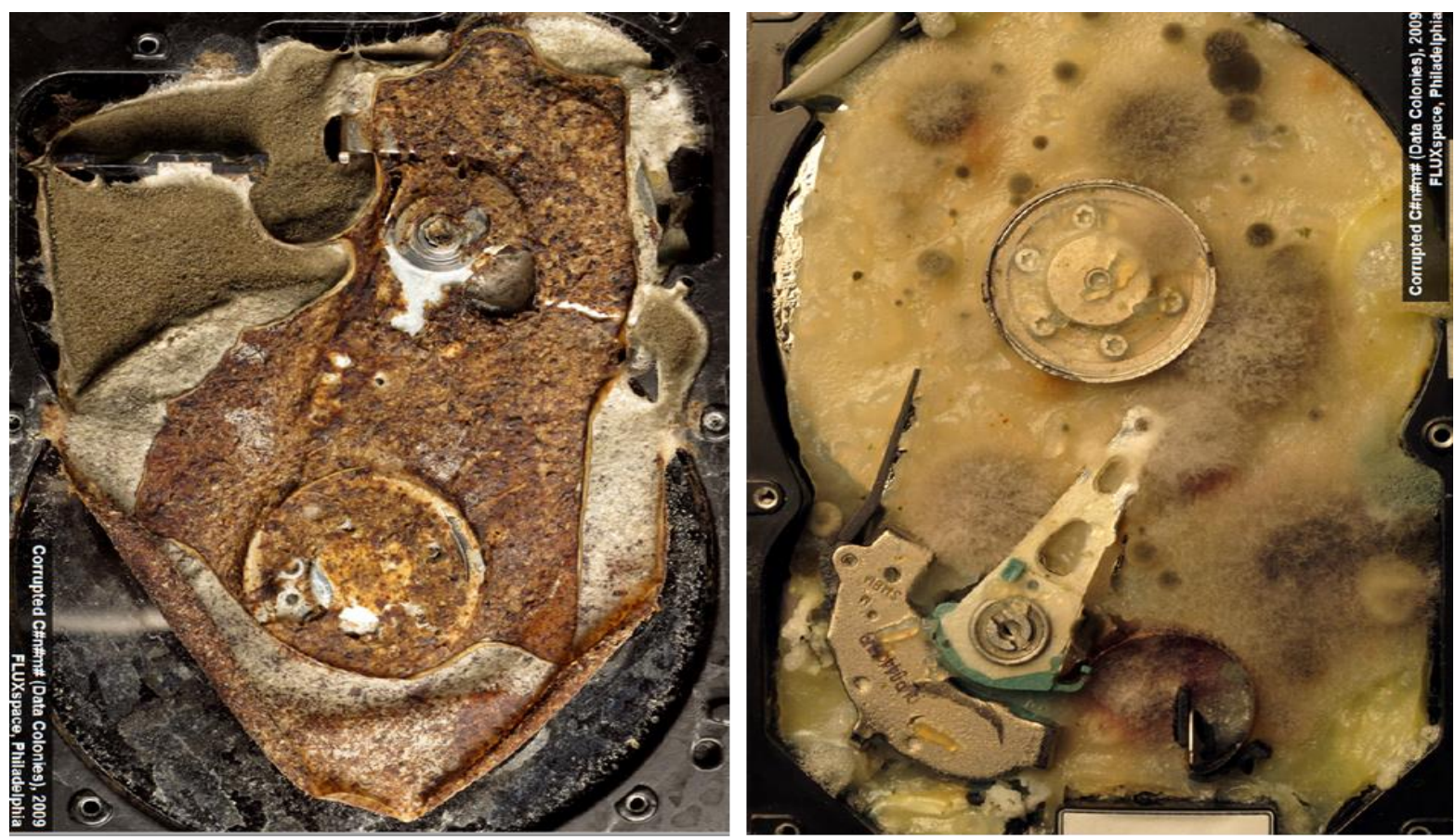

Figura 4: "Corrupted C \# n \# m \#” (montagem autoria minha), Angelo Vermeulen, 2010. - Fonte: site do artista.

Em uma série de procedimentos e configurações altamente agressivas, as mídias de armazenamento, como discos rígidos, cartões de memória e fita digital, são expostas a bactérias, fungos, algas, insetos etc. As informações e os dados de vídeo que foram danificados pela ação química e biológica dos microrganismos são meticulosamente recuperados por técnicas forenses de dados, e transplantando-se para os componentes em unidades de hardware não 
infectadas. O resultado são imagens parasitadas, imagens corrompidas pelos microrganismos. Como se a vida instaurasse um ruído, um fragmento no virtual e no digital ${ }^{4}$.

Para Serres, o parasita é apresentado como um ruído, que tanto pode ser destrutivo para a vida e como pode fazer nascer na vida uma nova ordem, ainda mais complexa. Para Deleuze, o ser simbiótico/parasita poderia ser definido por um grau de potência singular e, por conseguinte, por certo poder de afetar e de ser afetado. (SILVA, AMORIM e ANDRADE, 2007, p. 5637).

Corrupted C \# n \# m \# é uma investigação artística e ao mesmo tempo xamânica ${ }^{5}$ sobre a fisicalidade da mídia digital e explorando os limites do cinema experimental. Uma das últimas fases deste projeto foi a utilização das baratas entomográficas - Madagascar, em que foram transformadas em "insetos cibernéticos" capazes de interromper e danificar os dados das imagens presentes nos arquivos.

"O ruído-parasita interrompe o discurso. Todavia, tem a capacidade de provocar um sistema novo, uma ordem mais complexa, muitas vezes um sistema inverso e contraditório". (SERRES apud CORREIA, 2012, p. 33).

A ideia de utilizar seres vivos (microrganismos e insetos) para criar modulações nos dados digitais cria uma nova simbiose e sincronicidade entre os seres vivos e os digitais, apontando novas diretrizes tanto para a arte do futuro, como no próprio futuro da arte.

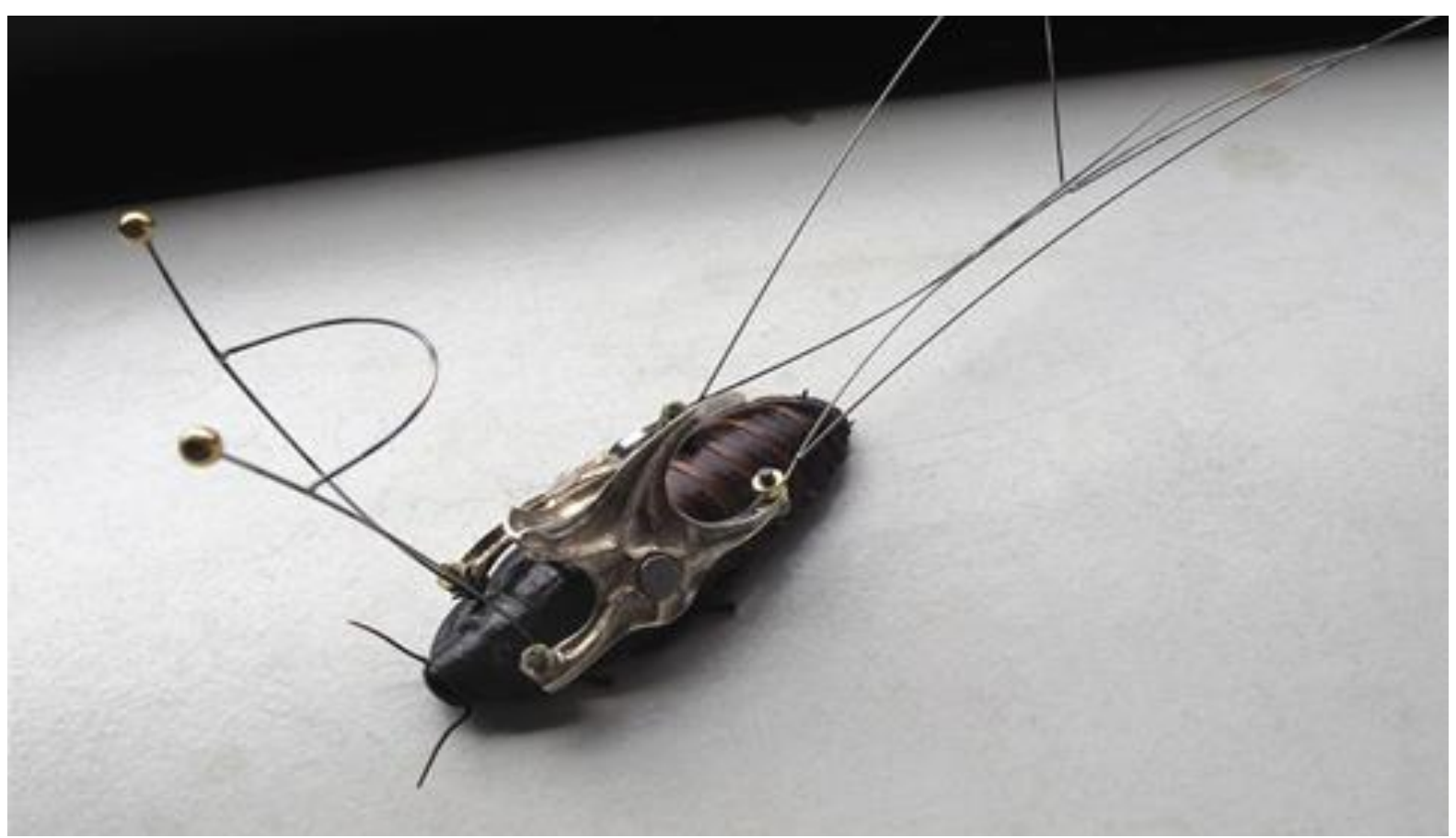

Figura 5: "Corrupted C \# n \# m \#”. Angelo Vermeulen, 2010. - Fonte: site do artista.

Essas experimentações artísticas, entres as interfaces seres-máquinas-digitais, trazem novas vertentes para as relações entre a natureza e a tecnologia, e nessa relação interespecífica

\footnotetext{
${ }^{4}$ Ver em: http://www.angelovermeulen.net/wp-content/uploads/2015/02/c011.jpg.

${ }^{5}$ Xamânica, que de acordo com Simondon (2015), o primeiro tecnólogo é o xamã (uma tecnologia diferente das nossas, outros processos de individuação e modulação da imagem), que nem sempre a tecnologia que vem depois é melhor que a que vem antes, nesse sentido, os organismos primitivos-bactérias, fungos e outros microrganismos tem potenciais tecnológicos potentes e provocam individuações no outro.
} 
entre organismos e máquinas, criam-se possibilidades infinitas de pensar novas redes de exploração e conexão entre tecnologias muito dispares.

Nesse sentido, o projeto Corrupted $\mathrm{C} \# \mathrm{n} \# \mathrm{~m}$ \# vai conhecendo e explorando as modulações entre organismos e máquinas que coexistem numa aproximação ao máximo que se encontra na relação da simbiose, do parasitismo e da protocooperação.

Um corpo uma vez infectado jamais volta ao seu estágio anterior. Em Corrupted C \# n \# $\mathrm{m} \#$ as imagens quando parasitadas ou em simbiose entram em estágios de devir.

Talvez, o que possa ser interessante são as vazões e os ruídos que tal invasor provoca, trazendo ao corpo modificações, perturbações que impulsionam para uma força ativa e re-ativa. Corpo antes acomodado, seguro, conformado, agora passa a se movimentar, criar novas formas de existência. (SILVA, AMORIM e ANDRADE, 2007, p. 5638).

Os estágios de devir são estágios de individuações entre os encontros e processos dos diferentes seres. Seres orgânicos e inorgânicos nas diferentes obras de Vermeulen agenciam estágios de devires entre a máquina e a natureza, entre o orgânico e o inorgânico, dando a vida e as imagens novas modulações.

Os trabalhos Biomondd e Corrupted C \# n \# m \# agenciam individuações, modulações, encontros e relações entre diferentes seres orgânicos e inorgânicos. Interessamos pelos movimentos de codificação e decodificação engendrados pelos parasitas e seres capazes de protocooperar, organismos que estabelecem outra ordem, que alteram padrões em diferentes estruturas, até mesmo virtuais.

O parasita é um ser agente de individuações coletivas. "Todavia, tem a capacidade de provocar um sistema novo, uma ordem mais complexa" (SERRES apud CORREIA, 2012, p. 33). Pura simbiose entre a natureza e a máquina, pura filosofia da relação, abrindo novos intervalos e modulações nas imagens.

O vivo vive no limite de si mesmo, sobre seu limite... A polaridade característica da vida está ao nível da membrana; é neste terreno que a vida existe de maneira essencial, como um aspecto de uma tipologia dinâmica que mantém ela própria a metaestabilidade pela qual ela existe... Todo o conteúdo do espaço interior está topologicamente em contato com o conteúdo do espaço exterior sobre os limites do vivo. (DELEUZE, 1974, p. 106-107).

Aprendemos em Deleuze, pensar a vida como uma grande multiplicidade, que se reinventa a todo momento, puro fluxo de agenciamento para pensar e explorar as modulações ao qual a máquina pode permitir, para além do que ela permite, visto que muitas vezes os microrganismos forçam aos dispositivos uma nova relação de modulação.

Nesse sentido, que os experimentos, como o Biomodd e Corrupted C \# n \# m \#, possam trazer importantes exemplos de processos de individuações entre o objeto técnico e os seres vivos, à medida que experimentam novas interações e possibilidades de existências entre a técnica, o objeto e a natureza. Nos diferentes experimentos, o ser e a máquina é limite e ilimitado ao mesmo tempo, é atravessado por si mesmo, esparrama incompativelmente sobre si mesmo, inventando novos acoplamentos metaestáveis.

Forma y materia, realidades anteriores al individuo y separadas entre sí, pueden ser definidas sin consideración de su relación com el resto del mundo, (...) Pero el sistema energético em el cual se constituye un individuo no es más 
intrínseco con relación a este individuo de lo que es extrínseco; está asociado a él, es su medio asociado. (SIMONDON, 2015, p. 60).

Ser vegetal, mineral, animal, máquina passar por todos esses reinos, trocas, fluxos, simbioses, parasitismos, ser atravessado por todas suas forças, mas sem fixar em nenhuma forma, ser todos e não ser nenhum. "Todo puede ser individuo, y nada puede serlo completamente" (SIMONDON, 2015, p. 65).

Com a individuação, o indivíduo se desfaz para habitar a informação. Nesse sentido diferentes seres se relacionam e experimentam processos de diferenciação de si mesmo e produção de novas imagens.

As diferentes obras apresentadas versam sobre esses outros modos de existência dos objetos, seres e coisas, instalam processos de individuações constantes entre as imagens e seu entorno.

As obras de Fernando Vicente nos convidam a escapar da submissão e da subordinação maquínica, e cibernética defendida por Donna Haraway entre outros autores, já as obras de Angelo Vermeulen trazem questões desafiadoras sobre as experimentações com microrganismos e insetos em mídias e seus efeitos sobre as imagens e seus fluxos internos e externos nas aproximações com as noções de individuação e modulação propostos por Simondon.

Nas diferentes produções artísticas apresentadas nesse artigo percebemos que o orgânico e os sistemas artificiais estão cada vez mais numa estreita simbiose com o tecnológico, artificial e natural na interface entre o físico, o real e o virtual, e o digital.

Ao estudar essas produções artísticas, percebemos que a tecnologia e a máquina não são apenas apresentadas como uma simples ferramenta, VHS, CDROM, placas de silício, entre outras diferentes manifestações da tecnologia, são acoplados aos seres vivos e vice e versa, a serviço de uma poética e estética. Assim, seres orgânicos e inorgânicos evoluem conjuntamente para novas interfaces do ser. É nesse cenário que nossa pesquisa inventa outras narrativas para pensar a relação entre ciência, arte e filosofia.

A arte contemporânea vem abrindo novas possibilidades de pensar a natureza, a ciência e a própria arte e seus expectadores.

O artista não é mais aquele que se expressa por meio de uma matéria, mas aquele que cria dispositivos capazes de tornar visível e sensível uma nova situação de vida e de tecnologias. Provocando o que Costa chama de 'ultrapassagem da dimensão artística em direção ao sublime tecnológico'. (SAMPAIO, 2012, p. 94).

Nesse ensaio refletimos sobre a noção de natureza e máquina em algumas produções contemporâneas, através de diferentes e inusitadas produções artísticas, tais obras, trazem novas experiências às Ciências, Arte e Filosofia pondo-se em relação a esses campos de conhecimentos.

Pensamos que os encontros inesperados entre a Arte, a Filosofia e a Ciências podem trazer algumas abordagens e reflexões para pensarmos as naturezas e máquinas para o amanhã, de forma crítica e com novas estratégias de mediação cultural, dando possibilidades de ampliar nosso repertório cultural.

\section{Referências}

DELEUZE, Gilles. Lógica do Sentido. Trad. Luiz Roberto S. Fortes. São Paulo: Perspectiva, 1974.

DELEUZE, Gilles., GUATTARI, Félix. O que é a filosofia? Trad. B. Prado Jr. e Alberto A. Munõz. 3. ed. São Paulo: Editora 34, 1992. 
DELEUZE, Gilles., GUATTARI, Félix. Mil platôs: capitalismo e esquizofrenia, v. 4. São Paulo: Ed. 34, 1997.

CORREIA, António Miguel B. Do parasitismo à simbiose: a responsabilidade ecológica em Michel Serres. 2012. Dissertação (Mestrado). Faculdade de Letras da Universidade do Porto. Disponível em: https://sigarra.up.pt/flup/pt//pub_geral.show_file?pi_gdoc_id=505277. Acesso em: 01 maio 2020.

HARAWAY, Donna. Manifesto ciborgue: ciência, tecnologia e feminismo-socialista no final do século XX. In: TADEU, T. (Org.). Antropologia do ciborgue: as vertigens do pós-humano, Belo Horizonte: Autêntica, 2009.

LYOTARD, Jean François. O inumano: considerações sobre o tempo. Lisboa: Editorial Estampa, 1997.

SAMPAIO, Valzeli Figueira. Arte e vida: desatando os nós - estudos e levantamento de relações nas mídias locativas. Estágio pós-doutoral. São Paulo: Escola de Comunicação e Arte da Universidade de São Paulo (ECA/USP), 2012.

SILVA, Antonio A.; AMORIM, Antonio C. R.; ANDRADE, Guilherme T. B. Ecologias parasitas na arte: encontros (im)possíveis entre Deleuze e Michel Serres. In: X CONGRESO INTERNACIONAL SOBRE INVESTIGACIÓN EN DIDÁCTICA DE LAS CIENCIAS, Sevilla, 2017. Disponível em: https://ddd.uab.cat/pub/edlc/edlc_a2017nEXTRA/01_Ecologias_parasitas_na_arte.pdf. Acesso em: 18 mar. 2020.

SILVA, Antonio Almeida da. Laboratórios dos despropósitos: vestígios ecológicos entre arte e ciência. Tese (Doutorado) - Universidade Estadual de Campinas, Faculdade de Educação, Campinas, SP, 2018. Disponível em: http://www.repositorio.unicamp.br/bitstream/ REPOSIP/332709/1/ Silva_AntonioAlmeidaDa_D.pdf. Acesso em: 27 abr. 2020.

SIMONDON, Gilbert. La individuación a la luz de las nociones de forma y información. Trad. Pablo E. Rodriguéz. Buenos Aires: Cactus, 2015.

TADEU, Tomaz. Nós, ciborgues. O corpo elétrico e a dissolução do humano In: TADEU, T. (Org.). Antropologia do Ciborgue: As vertigens do pós-humano, Belo Horizonte. Autêntica, 2009. 